\title{
A escrita como instrumento perverso: um estudo de La marchande d'Enfants de Gabrielle Wittkop
}

\author{
Anne Louise Dias*
}

\section{Resumo}

O presente artigo deseja analisar o romance La marchande d'enfants, escrito por Gabrielle Wittkop e publicado postumamente, em 2003, propondo-se a desvelar os mecanismos perversos de um texto que vai para além da religião, da moralidade e coloca a perversão como motivo de sua narração. Wittkop tentaria, por meio de uma escrita poética e perversa, alcançar o extremo, o absurdo ao fazer conscientemente uso da violência própria à linguagem, atacando, penetrando e testando as fronteiras do eu e os limites da representação. Nesse sentido, é nosso objetivo analisar, em La marchande d'enfants, o uso de um duplo jogo da linguagem, que joga com a imagética e a imaginação e, sobretudo, engaja seu leitor a tornar-se cúmplice das ações violentas ali postas em cena.

Palavras-chave: Gabrielle Wittkop. Imaginação. Perversão. Escrita. Leitor.

\section{Writing as Means of Perversion: a Study of La marchande d'enfants by Gabrielle Wittkop}

\begin{abstract}
This article aims at analyzing the novel La Marchande d'enfants - written by Gabrielle Wittkop and posthumously published in 2003 - by proposing the unveiling of the perverse mechanisms of a text that goes beyond religion and morality and, moreover, establishes perversion as the primary cause of its own narrative. Wittkop strives, through both poetic and wicked writing, to reach the extreme and the nonsense by consciously employing violence inherent to language, by attacking, piercing and testing the edges of the self and the boundaries of representation itself. Within this framework, it is our objective to analyze in La Marchande d'enfants the use of a double-faced game of language, a game that comprises both imagism and imagination and, most importantly, engages the readers in turning themselves into accomplices of such violent actions as those portrayed throughout the novel.
\end{abstract}

Keywords: Gabrielle Wittkop. Imagination. Perversion. Writing. Reader.

Recebido: $15 / 01 / 2018$

Aceito: 07/05/2018

1 Universidade de Brasília (UnB) - Mestra em Literatura e Práticas Sociais. 


\section{Introdução}

O instinto de imitação parece ser o ponto de partida do pensamento humano. Dentro dessa perspectiva, essa operação seria absolutamente indispensável à razão, que só seria capaz de conceber algo ao representá-lo como objeto mental. Heidegger em Holzwege $^{2}$ defenderia, ainda que, quando o mundo se torna imagem, tal é o processo pelo qual o homem, dentro do existente, se converteria em sujeito. Nesse sentido, a imagem de mundo equivaleria ao mundo captado como imagem. Enquanto cientificamente legitimada, a representação converte-se em categoria central dentro do âmbito da razão humana e, por isso mesmo, automatizada, passa a ser considerada como o único meio pelo qual seria possível ao homem apreender o mundo exterior. Mas, para termos acesso ao outro, ao real, seria preciso cruzar os limites desse modo de pensar, uma vez que a representação fundada na correspondência com as formas orgânicas da natureza não possuiria a capacidade de captar a variedade quase infinita das nuances do real. Este é o desafio da representação artística e literária e, especialmente, o de Gabrielle Wittkop, pois tudo o que escapa à representação detém um poder místico - a representação é, portanto, ela própria um meio de subversão.

A biografia de Gabrielle Ménardeau-Wittkop parece, aliás, ecoar da liberdade que ela tanto prezou em seus escritos. Viveu e morreu como um "homem livre", em suas próprias palavras. Fascinada pela imagem dos tigres, Gabrielle Wittkop - como preferia assinar seus escritos - viajara por todos os cantos do mundo, especialmente pela Indonésia e Índia. Durante a ocupação nazista na França, ela conheceu Justus Franz Wittkop (1899-1986), um desertor alemão homossexual, com quem se casou e se instalou em Frankfurt, onde viveu até seu suicídio, aos 82 anos, em 2002. Instalada na Alemanha, Gabrielle Wittkop continuaria a escrever em francês, mas desenvolveu ali sua escrita em alemão, tendo colaborado com vários jornais locais, entre eles o Frankfurter Allgemeine Zeitung. Seu primeiro romance, Le nécrophile, foi descrito por François Busnel como expressão do nascimento de uma escrita feminina sadiana, devido à ousada criação de um texto que combinaria amor, luxúria e depravação. Gabrielle Wittkop, tantas vezes acusada de 'diabólica' e 'perversa', acatou com lucidez a alcunha de monstruosa e La marchande d'enfants, já completo desde 1976, foi publicado apenas postumamente. Nele, Wittkop constrói um romance epistolar cujas cartas narram em detalhes o cotidiano de uma traficante de crianças no libertino mercado sexual da França em plena Revolução. Narra também sobre corpos perfurados, mutilados, reduzidos a objetos sexuais nas mãos de uma cruel e nefária clientela. Nos limites da representação, no limiar do extremo, sua escrita nos aporta um desafio - o de ler, de sobreviver a suas duras e perversas descrições. Na representação da violência, um duplo desafio: como conseguir transmitir o pretenso horror da cena em sua completude? O sangue, a urina, as fezes, quando representados não possuem o odor, sua 'presença' é, portanto, reduzida à imagem. Ali, portanto, Wittkop nos desafia a imaginar - pois, ler uma obra como La marchande d'enfants exige abertura, força para superar a evocação grotesca, maléfica, perversa do violento, e talvez ainda mais do que coragem, exija imaginação:

A vida aporta muitas decepções, tanto às maquerelles quanto aos libertinos. São os contratempos que desapontam a indústria das primeiras, é a imaginação que promete aos outros de serem felizes, para mortificá-los ainda mais cruelmente. ${ }^{3}$ (WITTKOP, 2003, p. 68)

\footnotetext{
2 Caminhos de Floresta.

3 Tradução nossa. No original: La vie apporte beaucoup de déconvenues, tant aux maquerelles qu'aux libertins. Ce sont les contretemps qui déçoivent l'industrie des premières, c'est l'imagination qui promet aux autres d'être heureux, pour ne les mortifier que plus cruellement.
} 
De fato, dentro do imaginário libertino, da perversão da violência e dos limites da representação, para que possamos ser comovidos, perturbados, violentados, é preciso dar livre curso à imaginação.

A sociedade acatou Sade em seu lado 'sádico', reproduzindo a imagem desse louco pervertido a quem precisamos lacrar em masmorras, longe dos olhos de todos. Ao tomar essa posição, a sociedade se recusou a ler o texto sadiano como a obra de um escritor: as encenações sadianas são, então, admitidas como realidade, e recusadas como texto. Em uma entrevista concedida à Eric Dussert, para o jornal francês de literatura contemporânea Le matricule des anges, Wittkop afirma que "permanece bastante influenciada por Sade que é, na minha opinião, o maior dos estilistas. No século XVIII La Mettrie, Condillac, d'Holbac são pensadores, não estilistas. Sade não envelheceu. Ele tem uma verve imprecatória, uma força verbal..."4.

Em La marchande d'enfants, Gabrielle Wittkop acata a filosofia lúbrica de Sade, reconhecendo que o desafio da escrita está justamente em ter colocado em cena a palavra da qual ela mesma se abstém ou fracassa: na violência, no gozo. "A linguagem comum recusa-se à expressão da violência, a que ela não concede senão uma existência irregular e culpada. Ela a nega, retirando-lhe toda razão de ser e toda justificativa"', afirma Bataille (1987, p. 122), em O erotismo. Mas é ali, pela 'representação', que Wittkop se propõe a realizar todos os fantasmas da imaginação do homem, forçando, para dentro do texto, todos seus delírios mais perversos e recuperando essa força verbal que ela atribui a Sade. Dedicar-nos-emos a analisar aqui a forma pela qual Wittkop convoca a imaginação do leitor como ferramenta da criação literária, consolidando dentro de sua obra o espaço não apenas do experimento das fronteiras da representação, mas também o espaço do leitor como cúmplice da obra perversa, adentrando assim, as ruelas da mais profunda crueldade: a natureza humana.

\section{A imaginação}

A tradição filosófica ocidental, segundo Cynthia Fleury (2006, p. 9), frequentemente duvidava da faculdade da imaginação. A ideia de que a imaginação pudesse ser ativa e agente, ou ainda, que ela possuísse uma função cognitiva própria era impensável, de forma tal que as fronteiras entre filosofia e poesia, mundo real e mundo fictício, razão e imaginário eram intransponíveis. Seria preciso esperar Descartes para que a filosofia desse novo rumo ao entendimento da imaginação. Séculos depois, com Kant, a imaginação ultrapassaria a função de subordinada ao entendimento, e na experiência da beleza, imaginação e entendimento se encontrariam.

Se existe sempre um espaço vazio entre a imagem e o real, quando perpassado pelas palavras, e se ali perde uma significação que não pode ser recuperada pela escolha das palavras, é pelo acionamento da imaginação do leitor que Wittkop procura superar as limitações da representação. A cena que não poupa o leitor dos detalhes: esta parece ser a cena wittkopiana por excelência. O projeto de escrita de Wittkop estaria, então, por entre a representação da violência - pela apresentação de cenas de assassinatos, tortura, estupros - e a violência da representação, ao incutir em seu romance a força própria da representação e da linguagem. Em La marchande d'enfants, "o mal está feito e a imagem de um inelutável inferno gravada para sempre"\% (WITTKOP, 2003, p. 65).

Testar os limites da imaginação libertina, a imaginação intercambiável à linguagem, nada mais seria do que testar seus limites próprios. Essa 'ficção sobre o mal'7, que seria em si uma violência,

4 Tradução nossa. No original: [je] reste très influencée par Sade qui est à mon avis le plus grand styliste. Au XVIIIe La Mettrie, Condillac, d'Holbac sont des penseurs, pas des stylistes. Sade n'a pas vieilli. Il a une verve imprécatoire, une force verbale...

5 Tradução de Antonio Carlos Viana. No original: Le langage commun se refuse à l'expression de la violence, à laquelle il ne concède qu'une existence indue et coupable. Il la nie en lui retirant toute raison d'être et toute excuse.

6 Tradução nossa. No original: le mal est fait et l'image d'un inéluctable enfer gravée pour jamais.

7 Tradução nossa. No original: fiction of evil. 
não existiria apenas para introduzir uma indefinida repetição do prazer, a mecânica de sua escrita é um movimento que age sob o princípio do excesso e do extremo - ela permite à imaginação exceder seus próprios limites. E seria por causa dessa 'ilimitabilidade' produzida pelo fato da escrita, segundo Foucault (2015, posição 1707) ${ }^{8}$ que o desejo vai em si se tornar a sua própria lei; ele irá se tornar um soberano absoluto encarnando sua própria verdade, a sua própria repetição, a sua própria infinitude, os seus próprios meios de verificação. Nada poderia negar ao desejo libertino a sua totalidade.

"Estais com medo de mim? - Medo, não, mas não te concebemos", responde Juliette quando na casa de Durand. De fato, o horror é uma questão de concepção. O excesso de tudo na cena wittkopiana, da violência, do sacrilégio, da crueldade, faz dessa "não totalidade", por vezes, tão atemorizante que a primeira resposta ao texto parece ser a da recusa, por vezes parece a única. $\mathrm{O}$ estranhamento se aprofunda quando nos depararmos com a amálgama dos assuntos macabros e do estilo clássico de Wittkop, criando uma prosa que "conjuga o extremo refinamento de um vocabulário frequentemente culto e raro e um trabalho com as sonoridades que dão a sua escrita uma dimensão poética incontestável" . O poético de sua obra estaria, assim, diretamente relacionado a seu conteúdo perverso. Seu horror apareceria ainda atenuado pela natureza fantástica dos atos aos quais algumas das vítimas infantes são submetidas. Por vezes, o ajuste teatral das representações postas em cena parece compor um exercício tão teórico, poder-se-ia dizer, que nos convida a uma leitura muito mais simbólica ou psicanalítica do que 'realista'. Nesse sentido, as ações e as cenas das quais participam as personagens de Wittkop, como a aparição do conde sueco, um dos últimos clientes estrangeiros do estabelecimento de Marguerite, parece-nos particularmente significante dentro da narrativa de La marchande d'enfants. Esse conde,

é um homem bastante original, nada o diverte mais do que as mascaradas e é assim que, vestido de rato, ele se agrada em assustar as crianças. Sua fantasia é uma das mais singulares. É um traje de uma pelagem rasa e cinza, completado por um longo rabo rosado e luvas pelas quais se estendem garras afiadas. Toda a cabeça é emprisionada em um artifício que maravilhosamente imita a cabeça do rato, dispondo de uma abertura na frente da boca e, para a vista, dois buracos redondos pelos quais cintilam os pequenos olhos negros do conde. Ele realmente parece um enorme rato sobre seus dois pés, e jamais nós víramos algo tão natural nem, entretanto, algo tão extraordinário. [...] Marotte com seus quatro membros amarrados, o conde surgira por detrás de um biombo, aproxima-se saltitante e cuincando como os ratos. [...] Ainda cuincando e sibilando, o conde começa a lhe rajar o ventre e o colo, as luvas munidas de garras avançam rápido e deixam finas estrias sangrentas sobre a pele de Marotte, cujos olhos exprimem um incomensurável terror. Por fim, sem mais delongas, o conde estupra a pequena menina, que desmaia instantaneamente. ${ }^{10}$ (WITTKOP, 2003, p. 135-136).

\footnotetext{
8 Como a versão utilizada como referência em nossa pesquisa é uma versão Kindle, iremos, daqui para frente, indicar a posição do trecho dentro do dispositivo.

9 THÉBAUD, Anne. La mort à l'oeuvre, artigo escrito para La quinzaine littéraire em 2001. Tradução nossa. No original: conjugue l'extrême raffinement d'un vocabulaire souvent savant et rare et un travail sur les sonorités qui donne à son écriture une dimension poétique incontestable.

10 Tradução nossa. No original: C'est un homme fort original, rien ne le divertit mieux que les mascarades et c'est ainsi que, vêtu en rat, il se plaît à épouvanter les enfants. Son costume est de plus singuliers. C'est un maillot de fourrure rase et grise, complété d'une longue queue de peau rosâtre et des gants que prolongent des griffes acérées. Toute la tête est emprisonné dans un artifice imitant à merveille celle du rat, ménageant une ouverture devant la bouche et, pour la vue, deux trous ronds à travers lesquels scintillent les petits yeux noirs du comte. Il a tout à fait l'air d'un énorme rat debout ses deux pieds, et jamais on ne vit rien d'aussi naturel ni pourtant d'aussi extraordinaire. [...] Marotte ligotée et écartelée en bonne posture, le comte surgit de derrière un paravent, approche sautillant et couinant à la manière de rats. [...] Toujours couinant et sifflant, le comte commence à lui zébrer le ventre et la poitrine, les gants griffus vont bon train et laissent de fins grillages sanglants sur la peau de Marotte dont les yeux expriment une incommensurable terreur. Enfin, sans plus attendre, le comte viole la petite fille qui s'évanouit à l'instant.
} 
A mistura dos dois elementos, o fantástico e a violência, torna a imagem do estupro de Marotte profundamente surreal. Mas o 'onírico' da cena não recusa a totalidade do mal. Pelo contrário, esse movimento de tessitura textual, que costura as fronteiras do real e do quase-delírio, implicaria que é na ideia da transgressão, na quebra de tabus, que o perverso encontra o erótico, e não no ato em si. Para Foucault (2015, posição 1630), a primeira função da escrita seria, portanto, abolir a barreira entre realidade e imaginação. Escrever é aquilo que exclui a realidade; consequentemente, é aquilo que irá liberá-la, que irá remover todos os limites do próprio imaginário.

La marchande d'enfants se produziria, então, em uma derrapagem acessada apenas quando se penetra as terras da incredulidade. Nessa perspectiva, não é o real que horroriza, mas sua 'possibilidade'; não havendo desconexão entre as instâncias. Tratar-se-ia de defender a imaginação como uma faculdade de acesso à realidade, a uma realidade 'a mais', como se a faculdade da imaginação fosse a única forma de revelar o mundo em todas as suas complexidades.

Dessa forma, a libertinagem exigiria que adaptássemos nossa imaginação para uma história que reflete a lógica da perversão. A perversidade exige a cumplicidade dos corpos e, no texto, da imaginação. Seria, assim, a 'atmosfera' de terror, a 'ideia' do mal, desse homem transmutado em rato, que aparece sorrateiramente, da preparação mesma da cena, que possibilitaria o incômodo no romance de Wittkop. Não apenas a linguagem de se faz excessiva, buscando sempre a superação de fronteiras, mas, funcionando como sinônimos, também o seria a imaginação:

Pois essa passagem do excesso numérico ao excesso singular se faz sempre a partir de um ponto de saturação que, se ele não é o mesmo de um indivíduo ao outro, indica ainda assim, cada vez, que o deslizamento em direção à imaginação é indissociável da realidade concreta, ou mais exatamente, sobrevém somente após a assimilação violenta e glutona. Como se o campo do real desse, primeiramente, ser conhecido, explorado, invencionado, para que surja uma outra realidade a mais, o excesso imensurável que, determinando bruscamente a singularidade excessiva, rasga o horizonte e abre-se sobre a perspectiva imaginária. ${ }^{11}$ (LE BRUN, 1986, p. 290).

Para Annie Le Brun, o excesso perverso é um processo de afirmação excessiva, como se o sádico que não dominasse todas as vias do prazer - e para isso, ele deve 'tudo' realizar - não apenas seria vencido pelas leis da natureza, como também estaria condenado à inexistência. A tradição libertina de obedecer a uma dinâmica de excesso, de um excesso mecânico abre, assim, para o infinito do excesso lírico ${ }^{12}$.

Jogar com esse infinito de possibilidades seria, para o sádico, uma forma de rejeitar a finitude humana. $\mathrm{O}$ excesso imagético da narrativa de Wittkop não se definiria pura e simplesmente pelo monstruoso ou pelas aberrações, mas seria preciso que, no contexto do espetáculo ou da literatura, suas cenas produzissem efeitos de medo ou de riso nervoso, para que se criassem o estranhamento e o terror, implicando, assim, diretamente o leitor dentro do texto. A fórmula se concretiza com Lucile, uma criança devota filha de protestantes, paulatinamente encaminhada, ao longo da narrativa, ao suicídio. Convencida por Marguerite de que sua marca de nascença era, na verdade, uma prova de seu destino amaldiçoado, Lucile é diariamente confrontada com a inexorabilidade de sua ida ao Inferno. Um dia, Marguerite a deixa só na sala de seu estabelecimento e, garantindo que a pequena Lucile pudesse escutar tudo o que ela falava no cômodo vizinho, lamentou:

11 Tradução nossa. No original: Car ce passage de l'excès numérique à l'excès singulier se fait toujours à partir d'un point de saturation qui, s'il n'est pas le même d'un individu à l'autre, n'en indique pas moins, à chaque fois, que le glissement vers l'imaginaire est indissociable de la réalité concrète, ou plus exactement ne survient qu'après son assimilation violente et gloutonne. Comme si le champ du réel devait d'abord être connu, exploré, inventioné, pour que surgisse telle une réalité en trop, l'excès non mesurable qui, déterminant brusquement la singularité excessive, déchire l'horizon et ouvre sur la perspective imaginaire.

12 Para Michel Delon, em Sade: un athée en amour, a incapacidade dos homens de afirmar sua autonomia moral exalta uma imaginação que se afasta da realidade sensível para fazer existir outros mundos. 
- Que pena que uma criança tão interessante esteja prometida à danação eterna! [...] Não é assustador quando pensamos nos tormentos do Inferno? O calor ardente, os gritos horripilantes e ainda mais estridentes do que os que escutamos sair da boca dos bandidos executados pela roda na praça de Grève, um fedor cadavérico ao qual não saberíamos nos acostumar, as torturas infligidas pelos demônios, o desespero de saber a infinidade deste estado, a solidão do coração... [...]

A separação...

A violação permanente de todo pudor, do espírito e da carne...

A impossibilidade de escapar desses castigos...

$\mathrm{O}$ arrependimento que carcome por ter escolhido o mau caminho...

A recusa colérica de Deus... ${ }^{13}$ (WITTKOP, 2003, p. 63-64).

Nesse 'jogo', como a própria maquerelle o nomeia, a palavra é inscrita no âmbito do perverso, e se lança à descrição de um inferno dantesco. O inferno, ali, evoca as imagens da separação, da corrupção da carne e do espírito, e, por fim, da rejeição da fé. Não seriam esses os tormentos próprios de Justine, enquanto nas mãos dos libertinos? Marguerite abusa do doutrinamento cristão de Lucile, de suas 'quimeras', a fim de puni-la, de demonstrar-lhe os infortúnios que dele surgirão. De entranhar-lhe o mal.

Lucile, entretanto, não passa de um artifício de linguagem. É o leitor que, durante o processo de leitura, participa da cena e, sem realmente poder vê-la, ele pode fantasiá-la ${ }^{14}$. Ao passo que a jogatina se refina, esse dramutello $^{15}$ faria com que na organização de suas cenas, na minuciosa escolha imagética e vernacular, o leitor colaborasse com a construção delas, passasse ele mesmo a criá-las - jaz aí a semente do teatro do deboche sadiano, pois, se o efeito sobre o leitor wittkopiano é profundamente estético, ele é também teatral. Mas a recriação desse inferno não apenas implica o horror, ele faz surgir um fascínio pelo mal; as descrições dos horrores passariam a ser uma espécie de retórica do mal, que procura nada mais do que a sedução dos sentidos, o abalo das sensibilidades humanas. Não estaríamos longe do que Freud abarcaria, em Das Unheimliche, ao analisar O homem de areia de E.T.A. Hoffman. Freud assinalara ali o sentimento humano da estranha inquietude, que revolve em torno de um interesse mesclado à rejeição. Essa sensação de inquietante estranheza, de atração e de repulsa, segundo Freud, nos remeteria a algumas lembranças familiares recalcadas, reprimidas para manter o campo da consciência isento de perturbações conflitivas que podem vir à tona em determinadas situações causando uma sensação concomitantemente sinistra e familiar.

As descrições de La marchande d'enfants evocam o sentido da angústia, do mal-estar físico, mas, ao mesmo tempo, esse mal outro, o retrato do sofrimento humano que nos captura e penetra o 'eu', exigindo atenção. A imagem da morte, incutida em nossos imaginários por Wittkop, nos aterroriza,

13 Tradução nossa. No original: - Quel dommage qu'une enfant si intéressante soit promise à la damnation éternelle ! [...] N'est-ce point affreux quand on pense aux tourments de l'Enfer? La chaleur ardente, les cris affreux et plus stridents encore que ceux qu'on entend pousser par les bandits roués vifs en place de Grève, une puanteur cadavéreuse à quoi on ne saurait s'accoutumer, les tortures qu'infligent les démons, le désespoir de savoir cet état ne jamais devoir finir, la solitude du coeur... [...]

La séparation...

Le viol permanent de tout pudeur, dans l'esprit et dans la chair...

L'impossibilité d'échapper à ces peines...

Le regret rongeur d'avoir choisi la mauvaise voie...

Le rejet courroucé de Dieu.

14 Will Mcmorran defende em The Sound of Violence: Listening to Rape in Sade que, embora os libertinos sadianos costumem olhar e escutar, enquanto também se saciam utilizando os outros sentidos, a ausência do visual é ocasionalmente representada como fonte de erotismo.

15 Termo criado pela própria Gabrielle Wittkop, in: WITTKOP, 2003, p. 64. Seria preciso uma análise mais profunda da palavra para conseguirmos estabelecer o pretenso significado do termo, que parece formado pela junção de drama e, possivelmente, uccello, que em italiano refere-se, em sua acepção figurativa, a um pássaro de mau agouro e, no vocabulário vulgar, pode ser utilizado para referir-se ao pênis. 
mas também nos cativa em um sentido mesmo da magia. Mas Gabrielle Wittkop também demanda de seu leitor um trabalho de imaginação muito mais duro do que a leitura das imagens sangrentas que a escritora compõe em seu romance. Quando o excesso imagético não é mais o suficiente ${ }^{16}$, ela parece recorrer a certas provocações direcionadas diretamente ao leitor. Frases como "basta um pouco de imaginação"17 (WITTKOP, 2003, p. 21) ou "deixe cavalgar sua imaginação, cara Louise"18 (idem, p. 42), que aparentemente não são seguidas por descrições das cenas perversas que ali se sucederam, abrem espaço para uma outra forma de construção da imagem.

Como poderia o leitor se contentar com esse lapso narrativo da protagonista, em uma história na qual ela pode prover todos os tipos de sórdidos detalhes dos acontecimentos? E como poderia o leitor não se sentir desafiado a, ao menos, tentar imaginar o que poderia vir a acontecer no estabelecimento de Marguerite, uma vez que ele está a par das violências, dos fetichismos que são encenados no quarto da devassidão? Essas ‘reticências' não são por acaso. Na menção aos ‘jogos de cirurgião', Marguerite abre o espaço para que o leitor, ele próprio, crie a cena de violência:

Eu gostaria de vos ter escrito ontem, mas Monsieur e Madame Montiel, tendo me demandado alguns bebês para brincarem de cirurgião, tive que ir os apanhar ao longo de Saint-Jean, onde eles são raramente escassos. Eu colhi três deles, duas meninas e um menino, recémnascidos, rosas, prontos para serem colocados sobre a mesa. Só o Satã sabe o que irá lhes acontecer. Geralmente, começa-se pelos olhos. ${ }^{19}$ (WITTKOP, 2003, p. 37).

Não somente o diabo saberá o que lhes acontecerá, o leitor também. Frente a esses convites feitos pela narradora, esses convites abertos à imaginação, Wittkop demonstraria que também o leitor está escrevendo o roteiro de La marchande d'enfants. Ao analisar Les Cent Vingts, Annie Le Brun (1986) sustenta que o inacabamento do texto é um dos estilos mais provocadores, pois sugerem que, na possibilidade da continuação, do preenchimento dos vazios, o leitor faça parte do processo criativo da narrativa sadiana. Parece-nos correto afirmar, portanto, que o romance de Wittkop se constrói pela insinuação das imagens. Mesmo em trechos nos quais Marguerite nos dá alguns detalhes do que havia ocorrido, como no encontro amoroso com Tirésias, haveria uma brecha para o instalar da atividade imaginativa:

Como vos reproduzir, cara Louise, a noite que passei com Tirésias? [...] Eu, eu não tinha dedos o bastante para explorar esse charmoso corpo, não tinha braços o bastante para apertá-lo contra meu seio, não tinha lábios o bastante para lhe cobrir de beijos insistentes e profundos. [...] Tudo fora palpitações, tumescências, enrijecimentos, tensões, efusões, rosáceos, licores, solavancos e suspiros. ${ }^{20}$ (WITTKOP, 2003, p. 113).

Não há na cena imagens definidas, mas espécies de silhuetas, indicações. É a força, a sensibilidade do encontro que encarregaria de impelir o leitor a criá-la. O movimento é uma abordagem também sentimental; transformando a perversão em paixão, Wittkop aproveita da própria bagagem emocional do leitor para a construção da cena amorosa - ela deseja que o leitor ali se encontre, ali se imagine.

Sob essa perspectiva, o final inconclusivo de La marchande d'enfants não causaria mais certo

16 When excess isn't enough, expressão de Paul Young.

17 Tradução nossa. No original: Il ne faut qu'un peu d'imagination.

18 Tradução nossa. No original: Laisser trotter votre imagination, chère Louise.

19 Tradução nossa. No original: Je voulais vous écrire hier mais Monsieur et Madame Montiel m'ayant demandé des bébés pour jouer au chirurgien, j'ai dû aller en quérir au tour de Saint-Jean où ils ne manquent guère. J'en ai récolté trois, deux filles et un garçon, frais pondus, roses, prêts à être mis sur table. Satan seul sait ce qu'il leur arrivera. En généralement on commence par les yeux.

20 Tradução nossa. No original: Comment vous dépeindre, chère Louise, la nuit que je passai avec Tirésias ? [...] Moi, je n'aivais pas assez de doigts pour explorer ce corps charmant, pas assez de bras pour le presser contre mon sein, pas assez de lèvres pour le couvrir de baisers insistants et profonds. [...] Ce n'était que palpitations, gonflements, roideurs, tensions, épanchements, rosées, liqueurs, soubresauts et soupirs. 
estranhamento, pois mais do que um final insatisfatório, é uma pergunta ao leitor, é a abertura das possibilidades:

Eu perguntei por todos os lugares em Paris sobre notícias de Marguerite Paradis, a todos que a conheciam, mas ninguém pode me informar onde ela se encontra. Não se sabe se ela emigrou ou se ela perecera. Uma velha senhora me dissera apenas que uma pessoa, cujo nome ela havia esquecido, teria dito, em confidência, ter escutado que Marguerite teria comparecido ao tribunal revolucionário, denunciada por uma surda e muda que não sabia escrever, o que não faz o menor sentido. Para outros, ela teria sido massacrada em plena rua, outros teriam, no entanto, a visto sendo levada na charrete de Sanson, outros garantem que ela teria se salvado [...]..$^{21}$ (WITTKOP, 2003, p. 173)

Mais do que um artifício retórico, afirma Paul Young (2008, p. 145), essas lacunas seriam uma exigência própria ao texto. Se um autor pede ao seu leitor para preencher os espaços vazios de sua narrativa, pede para imaginá-los, é porque ele tem confiança de que seu público é capaz de fazê-lo. Nesse sentido, sustentar-se-ia a ideia de que não apenas a imaginação de Wittkop teria os meios de criar as cenas perversas, de sonhar com esses pesadelos; eles são frutos diretos também da imaginação do leitor, ou melhor, da imaginação do homem como faculdade cognitiva.

Um texto sobre o mal pode ser, então, um mal em si mesmo. E o texto wittkopiano criaria, portanto, mecanismos dentro de sua estrutura textual que agiriam como dispositivos perversos. Ao forçar o leitor a desenvolver uma espécie de competência narrativa que, para Cynthia Fleury (2009, p. 15) poderia ser chamada de 'competência imaginal'22, os leitores poderiam aprender a organizar suas próprias experiências; no caso de La marchande d'enfants, ele aprenderia a remontar a narrativa perversa.

A violência, que de alguma forma é sempre um atentado contra o íntimo, toma a imaginação como o meio último de seu fim. Através da violência, é possível transmutar o ser, de 'corromper sua verdade' - mais ainda, de aflorá-la, esta imaginação libertina. Encontrando-se em uma encruzilhada, o leitor é transformado, pela pluma de Wittkop: doravante ele é capaz de imaginar, criar e encenar o crime. De fato, é no processo da leitura que o leitor não apenas reatualiza o crime instaurado pela maquerelle, mas é ele quem o põe verdadeiramente em ação - a leitura torna o mal um fenômeno inescapável. Gabrielle Wittkop realiza, portanto, a façanha de criar uma organização literária orgânica que se faz presente pelo par próprio do processo de escrita/leitura.

Escrever seria o epítome da violência, a escrita ela própria um instrumento de tortura. Ela representaria então a síntese ideal na relação dialética entre o discurso e a práxis. E, é por meio desse projeto literário, que Wittkop daria à violência uma voz. Nesse sentido, a escrita de ambos se assemelha à máquina da Colônia penal, uma máquina extremamente complexa e cujo objetivo não é o de provocar diretamente a morte. Em La marchande d'enfants, também a linguagem, como instrumento da imaginação, é uma forma de violação, de se inscrever na carne de quem o toca, de quem for condenado. Acreditamos que, instaurada como um exercício da crueldade libertina, a imaginação apareceria, em La marchande d'enfants, como um movimento indicativo do próprio ato da criação literária.

"Escrever era a loucura de Sade”, afirma Phillipe Sollers (2001). Para Wittkop, pelo contrário, escrever é um 'projeto de loucura', um projeto que exige a aceitação completa do crime, do mal, da

21 Tradução nossa. No original: J'ai partout fait demander à Paris des nouvelles de Marguerite Paradis à ceux qui la connaissaient, mais nul n'a pu m'apprendre où elle se trouve. On ne sait si elle a émigré ou si elle a péri. Une vieille femme m'a seulement fait dire qu'une personne dont elle avait oublié le nom aurait dit, sous réserve, avoir entendu que Marguerite aurait comparu devant le tribunal révolutionnaire, dénoncée par une sourde et muette ne sachant pas écrire, ce qui ne fait aucun sens. Selon d'autres, elle aurait été massacrée en pleine rue, d'autres pourtant l'auraient vue menée dans la charette de Sanson, d'autres assurent encore qu'elle se serait sauvée [...].

22 Tradução nossa. No original: compétences imaginales. 
perversão como um espetáculo, como uma experiência moral e estética e da disposição de recriá-la, de tomar a posição de ser criador; uma vez consciente de que a palavra abarca em si a re-atualização infinita do crime sadiano, abarca a possibilidade de sua fantasia, de seus fantasmas, "em suma, a escrita tornar-se-ia [...] 'o lugar do crime indefinido': o leitor sofreria plenamente o excesso, mais ainda do que o efeito, em uma experiência de leitura como posta à prova"23 (KOBER, apud VÁRIOS, 2005, p. 63). Paulatinamente corrompido, ele padeceria a cada página pela exposição do mal, do sujo, do que 'perturba', pois, de fato, a morte, ela desordena ${ }^{24}$.

Mas a tortura pode também arrebatar, fascinar. E é pela afirmação de um imaginário comum, perverso, libertino que a obra de Wittkop consegue alcançar seu público, consegue engajá-lo ao longo da leitura. Consegue seduzi-lo. Em uma das cartas na qual Marguerite descreve uma reunião orgiástica de seus clientes, ela insinua jocosamente a Louise: "certamente, cara Louise, vós vos perguntais onde estavam minhas mãos durante todo esse tempo..." ${ }^{25}$ (WITTKOP, 2003, p. 121). Agora imaginamos.

\section{A cumplicidade}

Assim, tanto a forma quanto o conteúdo da linguagem são absolutamente perversos na obra de Gabrielle Wittkop. Seu discurso do excesso satura as imagens violentas, mas também demanda que o próprio leitor encontre nelas a possibilidade do ir além; criando brechas, Wittkop almejaria uma 'corrupção generalizada' do imaginário de seu leitor, que será doravante reconhecido como companheiro libertino. Essa subversão do discurso literário, que inclui o leitor dentro do processo de escrita, faz parte do projeto de Wittkop, um projeto tal que começa na transgressão - no cruzar do limite, pois, se é dado ao discurso a possibilidade da perversão, também lhe é atribuído o poder de perverter. Deleuze (2009) afirma que não há nada mais distante do sádico do que a intenção de persuadir ou convencer. Trata-se de mostrar que o próprio raciocínio libertino é uma violência e que está do lado dos violentos.

Assim, a violência dessa experiência seria, antes de tudo, vivida pela 'carne' - tal como o corpo da vítima do herói wittkopiano é o lugar da expressão da violência libertina. Isso porque sua força advém de palavras que possuem poder sobre o corpo, instalam uma 'agitação' naqueles em que toca. 'Corrompe-os', por fim. Segundo Costa Lima (2000), a repercussão dessa ruptura vai ainda além, pois uma vez que compreendida como o fruto do processo imaginativo do artista, ela também simula e procura fechar seu ciclo criativo ao integrar o leitor junto ao processo de criação. Nesse sentido, a 'representação-efeito' - não exclusiva da arte - não tem compromisso com a reprodução do objeto, pois se atualiza em um sujeito na condição de receptor. O enunciado na obra de arte suporia, como vimos, o trabalho do receptor com os vazios que acompanham a cena textual ou pictórica. Talvez possamos, assim, pensar a recepção de obras perversas frente ao conceito de "jogo", como concebido por Schiller. Se, para ele, o homem só é de fato homem quando joga ${ }^{26}$, então quiçá exista um certo acordo no ânimo do receptor que aceite os termos de compromisso expostos pelo literário.

Para Farrar (2000), o maior dos prazeres libertinos não é a destruição das vítimas, mas a criação de algozes. Para ela, entretanto, os prazeres cruéis do libertino são de curta duração - esses prazeres morrem junto a suas vítimas. Mas se o libertino é um escritor que pretende enxergar o leitor como vítima, essa satisfação pode ser completamente obtida. A estrutura narrativa de La marchande

23 Tradução nossa. No original: En somme, l'écriture deviendrait [...] 'le lieu d'un crime indéfini': le lecteur en subirait pleinement l'excès, plus encore que l'effet, dans une expérience de lecture comme mise à l'épreuve.

24 WITTKOP, em entrevista à Mathieu Lindon do jornal francês Libération, em 19 de setembro de 1996. Tradução nossa. No original: ça fait désordre, la mort.

25 Tradução nossa. No original: Sûrement, chère Louise, demanderez-vous où j'avais les mains pendant ce temps...

26 E não seria Gabrielle Wittkop uma jogadora? 
d'enfants, nesse sentido, nos permitiria compreender o intento 'pedagógico' como duplo; enquanto Marguerite repassa, por meio de cartas, para Louise os seus conhecimentos acerca da profissão de maquerelle, o leitor também passa a ser ele próprio conhecedor de todos os truques.

A epístola, gênero poético clássico, foi, a partir de Horácio, um poema quase sempre em tom familiar, acerca de assuntos sentimentais ou filosóficos e morais. Com o passar dos séculos, o gênero toma a forma pela qual o conhecemos atualmente, até que o romance epistolar atingisse um enorme sucesso na Europa do século XVIII. As cartas atestam, por um lado, em Wittkop, o apreço pela pesquisa histórica e pela construção de um romance ficcionalmente ambientado no século da Revolução. Por outro lado, a estrutura narrativa transforma os ensinamentos libertinos em textos de tom familiar que fazem do leitor um correspondente direto. A violência se faz entrecortada por comentários pessoais sobre a moda, o clima e as dificuldades econômicas da cidade parisiense que revelam não apenas a banalidade do mal por entre os perversos, mas também um vínculo de intimidade entre o grupo. Intimidade essa que atinge diretamente o leitor de La marchande d'enfants.

O jogo propõe ao leitor a posição de voyeur/euse, e ao aceitar o desafio, o leitor se torna ele próprio parte da sociedade:

Tal cúmplice é, assim, eleito ao círculo do Mestre: o único lugar possível de reciprocidade, por meio do qual toda pretensão a outros discursos, que seria o discurso do Outro, é rejeitado. A cumplicidade do leitor elimina o derradeiro risco de contradição, e a conquista está agora completa. ${ }^{27}$ (HÉNAFF, apud ALLISON; ROBERTS; WEISS, 1995, p. 153).

Quiçá não tenha sido esse o objetivo de Wittkop ao adereçar suas cartas a uma amiga que aparecerá apenas ao fim do romance, quando o romance propõe uma quebra de sua estrutura. Enquanto Louise não responde explicitamente às correspondências da mercadora parisiense, é o leitor que carrega consigo a missão e o peso de ler essas cartas. É com ele que a narradora conversaria. Ali, ele é cúmplice e não pode mais denunciar os atos descritos porque agora faz parte do segredo. Ele tem o sentimento de acessar algo de proibido uma vez que permanece consciente que os excessos narrados e os segredos revelados não são para seus olhos. Hénaff (1995) completa: "ler já é uma conspiração"28.

Por meio das correspondências, Wittkop criaria a existência de um leitor com o qual ela deseja se comunicar, com quem ela sabe que pode se comunicar. A estratégia evoca o próprio Sade que costumava sumariamente alertar quem o lê. Embora La marchande d'enfants não possua nenhuma introdução similar aos moldes do marquês, a inclusão de um dos trechos de Les chants de Maldoror, de Lautréamont (outro autor com o qual Wittkop se identificava), no prefácio escrito por Delescluse, é revelador: "não convém que qualquer um leia as páginas que vêm a seguir; somente alguns saborearão esse fruto amargo sem perigo"29 (LAUTRÉAMONT, apud WITTKOP, 2003, p. 9).

La marchande d'enfants marca também uma provocação e um tipo de cumplicidade para com o leitor, permitindo-se a familiaridade. Aos moldes, de "hipócrita leitor, meu igual, meu irmão"30 de Baudelaire, as cartas seriam ilustrativas dessa relação autor-poeta-leitor, simulada pela presença do narratário. E criariam, dessa forma, uma ideia de fraternidade que ironicamente prospera dentro do âmbito da crueldade.

De fato, essencialmente, La marchande d'enfants é uma obra largamente adereçada a seu leitor: "o olhar direto e claro, armada de sua dignidade vertical, Gabrielle Wittkop exige tudo de seu leitor, mas não o deixa jamais se aventurar sozinho sem tê-lo prevenido anteriormente dos riscos que ele

27 Tradução nossa. No original: Such an accomplice is thereby elected into the Master's circle: the only possible place of reciprocity, by means of which every pretension to other discourses, which would be the discourse of the Other, is dismissed. The reader's complicity eliminates the ultimate risk of contradiction, and the conquest is now complete.

28 Tradução nossa. No original: to read is already to conspire.

29 Tradução de Cláudio Willer. No original: Il n'est pas bon que tout le monde lise les pages qui vont suivre: quelques-uns seuls savoureront ce fruit sans danger.

30 Tradução de Pietro Nassetti. No original: Hypocrite lecteur, - mon semblable, - mon frère. 
corre"31 (DELESCLUSE, apud WITTKOP, 2003, p. 10). Porém, essa visita guiada pelas cloacas parisienses do século XVIII faz parte de um princípio da ação perversa de sua narrativa. E as reações variam desde o tédio até o prazer ou uma dor extrema, passando pelo choque emocional que participa de uma interação prazer / desprazer. A gama de emoções que atravessa o leitor demonstra-nos que, seja contorcendo o leitor em forma de horror, de riso ou apatia, a parte libertina sempre vence.

Aqui a imaginação também ressurge como ferramenta de cumplicidade. Como vimos, impelir o leitor a imaginar, a fantasiar as lacunas vazias das cenas violentas ou mesmo da própria narrativa do romance seria uma forma de estabelecer que a imaginação humana não possui limites ou não seria presa aos grilhões morais e religiosos. É por meio da imaginação e dentro da imaginação que o homem tomaria corpo e ganharia sentido: como fonte fundamental do sentido, como realidade que funda, federa e fecunda a vida humana, a imaginação seria o elemento intermediador que permitiria aos indivíduos, aqui libertinos, de se compreenderem entre si, de apreenderem o mundo e de entenderem seu espaço nele.

O humor que perpassa La marchande d'enfants procuraria, então, investir na singularidade de sua onipotente força metafórica. Em vários casos, aliás, o uso do humor visual e verbal de Wittkop transformaria a violência em um ato farsesco. De fato, confrontando-nos com a interação entre Titus, um anão sifilítico de 23 anos, e Laustensoire, pedófilo que procurava "um Hércules de doze anos" ${ }^{\prime 32}$ (WITTKOP, 2003, p. 55) e importante cliente de Marguerite, Wittkop organiza um verdadeiro teatro, no qual se abre espaço para o absurdo que combina o 'grotescamente' cômico ao irracional da violência:

Tu terás também! grita o anão e, jogando-se sobre ele, lhe abate com a força de um desses Hércules dos quais Laustensoire tanto desejara a aproximação. O roupão de banho é abaixado sobre o cu cinza rato de Laustensoire, o qual Titus empala em menos de um instante. Mais forte do que a volúpia, o medo da sífilis subjuga Laustensoire que, sem conseguir livrar-se de seu domínio, rasteja pelo tapete como uma serpente, o anão cravado em seu cu. Os dois répteis progredindo assim dão toda uma volta no cômodo, depois chegam ao pé da mesa onde está servida uma refeição leve. Laustensoire se contorce belamente, tenta violentamente rechaçar Titus, agarra na toalha de mesa, se suspende, enquanto que capões, tortas, queijos e toda a louça tombam em um grande estrondo sobre esse casal de salamandras, bem no instante no qual Titus libera sua carga. [...] $]^{33}$ (WITTKOP, 2003, p. 71-72)

O absurdo toma ares de extremo quando levamos ainda em conta a cena em sua completitude. Um anão prostituto fantasiado "à nova moda infantil" ${ }^{34}$ (idem, p. 70) persegue um homem nobre, cujas filhas haviam anteriormente sido infectadas pelo próprio Titus; os dois acabam se chocando e caindo pelo cômodo, derrubando a comida da mesa sobre si mesmos. O estupro e consequente contaminação de Laustensoire parece quase se esvair, se esvaziar em meio às ações absurdas ali descritas por Wittkop, mas o arranjo singular da cena é, e continua sendo, sobretudo, uma questão da imaginação excessiva, de uma força da blasfêmia que a tudo vem balançar. Wittkop, trata às vezes

\footnotetext{
31 Tradução nossa. No original: le regard droit et clair, armée de sa verticale dignité, Gabrielle Wittkop exige tout de son lecteur mais ne le laisse jamais s'aventurer seul sans l'avoir prévenu des risques qu'il court.

32 Tradução nossa. No original: un Hercule de douze ans.

33 Tradução nossa. No original: Tu l'auras aussi ! crie le nain et, se jetant sur lui, il le terrasse avec la force d'un de ces Hercules dont Laustensoire avait si souvent souhaité l'approche. La robe de chambre est troussée sur le cul gris souris de Laustensoire que Titus empale en moins d'un instant. Plus forte que la volupté, la crainte de la vérole subjugue Laustensoire qui, sans parvenir à se dégager de l'emprise, rampe sur le tapis comme un serpent le nain rivé à son cul.Les deux reptiles progressant ainsi font tout le tour de la pièce puis parviennent au pied de la table où est dressée la collation. Laustensoire se tortillede plus belle, tente violemment de désarçonner Titus, s'agrippe à la nappe, s'y suspend, tandis que chapons, tourte, fromages et tout la vaiselle dégringolent à grands fracas sur ce couple de salamandres, à l'instant où Titus achève sa carrière. [...]

34 Tradução nossa. No original: à la nouvelle mode enfantine.
} 
com humor aquilo que, a seus olhos, não pode ser diferentemente. Nietzsche chegara a escrever que "ver naufragar as naturezas trágicas e poder rir disso, apesar da profunda compreensão, da emoção e da simpatia que se sente, isso é divino"35 (NIETZSCHE, apud BATAILLE, 1957, p. 45).

Outrossim, o humor característico do modelo de escrita wittkopiana ressignifica o cômico de forma a torná-lo também um artifício perverso - fazer rir da violência seria também uma forma de atingir, subverter. Segundo Lefort (2000, p. 78), provocar o riso já é uma forma de corrupção, porque insinua no leitor um pensamento que ele próprio é ensinado a combater. Rir da violência, aceitá-la como espetáculo é acatá-la em sua validade.

Ao falar de sua profissão, Marguerite confessa "É o que?... Nós nos insensibilizamos como de costume e, se deixássemos livre curso à piedade, não poderíamos exercê-la nem um dia sequer" ${ }^{36}$ (WITTKOP, 2003, p. 141). Porém, o lembrete não é para Louise, e sim um pedido para que o leitor participe do jogo literário, que escolhera na violência seu objeto de representação - esse é o pacto de La marchande d'enfants. E, uma vez aceito, o riso pode então ter livre curso:

Nem la Pinette nem la Scapulaire nem eu mesma havíamos visto coisa parecida e isso nos fora um espetáculo muito enriquecedor. Pouf-Pouf no sétimo céu, um pouco de sangue gotejando do cu e, tendo ejaculado como um ciclope, quisera, tão frívolo quanto podia ser, lavar ele mesmo os pés de seu caro monstro; depois, após ter comido chocolate conosco, os dois amigos partiram. ${ }^{37}$ (WITTKOP, 2003, p. 89).

Estabelecida a cumplicidade, surge, dessa vez, não um riso nervoso, que reage ao horror, mas um que enxerga toda a potencialidade da narrativa. Um riso que reconhece o texto wittkopiano enquanto descarga, catarse. A instalação do jogo perverso por entre as linhas de La marchande d'enfants partilharia, assim, das características dos jogos codificados, saídos de teatros de máscara e que permitiam transgredir o interdito, como afirma Georges Minois (2003, p. 166). Isso porque os jogos possuíam a função de liberar as necessidades recalcadas por um modo de existência excessivamente regulamentado; e, ao brincar com o conceito de perversão e de sua representação, Wittkop delinearia o perverso junto ao riso de forma tal que a própria perversão seria doravante desarticulada. Como não rir do absurdo da cena desse homem que havia acabado de ser penetrado por um monstro disforme, ainda sangrando, e que agora compartilha o chocolate? Rir com o libertino é encontrar o prazer na maldade. Mas, tal qual a população parisiense do romance, é abraçar o mal como espetáculo, como recriação estética.

A violência da representação é, portanto, dupla. Parte primeiramente do horror das imagens violentas, e segundamente da certeza do balançar dos sentidos. Aceitar o projeto de escrita de Wittkop, um projeto que refuta a conceptualização e a polarização rígida do bem e do mal, é aceitar se dar o direito à dúvida, à ambivalência, ao fora dos limites do racional. Escrever sobre a violência é, em Wittkop, uma forma de violência em si, porque nos alerta para sua existência, nos remete aos abismos da existência humana, porém nunca de uma forma acusadora. E é essa não acusação que penetra, são as curtas narrativas que (in)satisfazem e, com o passar da leitura, o sangue escorrido não incomoda mais - mas mesmo a apatia é uma violência em si. Sua clareza de estilo permite que, tal qual o dispositivo de Kafka, feito em vidro, quem está disposto a observar o castigo em ação, que o veja em toda sua completude.

35 Tradução Antonio Carlos Viana. No original: Voir sombrer les nature tragiques et pouvoir en rire, malgré la profonde compréhension, l'émotion et la sympathie que l'on ressent, cela est divin.

36 Tradução nossa. No original: Et quoi?... On s'y endurcit comme en toute chose et si on laissait libre cours à la pitié, nul ne pourrait l'exercer un seul jour.

37 Tradução nossa. No original: Ni la Pinette ni la Scapulaire ni moi-même n'avions vu pareille chose et ce nous fut un spectacle très enrichissant. Pouf-Pouf au septième ciel, un peu de sang lui perlant du cul et ayant éjaculé comme un cyclope, voulut, tout frivole qu'il puise être, laver lui-même les pieds de son cher monstre puis, après avoir pris le chocolat avec nous, les deux amis s'en sont allés. 
A intenção, entretanto, não é chocar. A violência posta em palavras se metamorfoseia em escritura violenta, fazendo-nos indagar se as representações da violência são mecanismos potenciais de violência cultural e, demandando, por fim, resposta ativa para as inquietações que delas advêm. A literatura de Wittkop quer romper com os discursos que estão encapsulados em estruturas institucionais e que excluem certas vozes, estéticas e representações. Na edição da revista Chronic'art de março de 2001, Wittkop afirmou que "se as pessoas estão chocadas, isso prova que elas são simplesmente 'chocáveis', é tudo!" 38 . A literatura de Wittkop, embora amplamente ancorada em questões de representação, como vemos em seu intenso trabalho histórico e estético, não seria apenas uma recriação plástica do que concebemos ser a literatura de Sade. Wittkop escreve por um poder transformador; transformador porque sua literatura exige presença, demanda atenção. Por entre sua estética, habita uma verdade que afirma que o monstro não é um fenômeno sem valor ou uma farsa da natureza. A sua literatura revelaria que os monstros, alegorias do tabu, são proteiformes e que devem também adentrar o campo da literatura.

Daí seu interesse pela escrita do divino marquês. Em um aspecto, La marchande d'enfants funciona como uma legitimação e reabilitação da obra de Sade. Em um outro, ela vem para mostrar que, embora a sociedade contemporânea se paute em uma suposta liberdade, a representação do tabu permanece interdita, permanece 'anormal', como vemos pelas inúmeras censuras que sofre a obra wittkopiana. A literatura que evoca o grotesco, o horror pede, então, passagem. Passagem para criar sem estar atrelada a questões morais. O trabalho poético de Gabrielle Wittkop é um trabalho de criação, de criação estética, imagética, literária. A dificuldade de abordar sua obra estaria, assim, no limite do que nós ainda vislumbramos ser o belo, o proveitoso. Ela questiona, ao mesmo tempo que questiona a moral, os valores cristãos, o material da literatura.

La marchande d'enfants atinge o campo da sensibilidade do leitor, reconhecendo o papel fundamental da literatura como exercício de reflexão e experiência da escrita, e respondendo a um projeto de conhecimento do homem e do mundo. A escrita de Wittkop seria o reconhecimento de que apenas a literatura dá voz ao bárbaro, ao cruel - de que apenas a arte pode dizer certas coisas. O que Gabrielle Wittkop reconhecia é que a única maneira de abrir mão do uso do estereótipo é através da própria linguagem, através da criação literária.

La marchande d'enfants não seria fruto de 'pose', 'provocação', 'teatralidade', 'afetação', mas de uma construção literária, que envolve tanto um projeto estético, linguístico e social, de um planeamento profundamente autoconsciente. Ao abordar o domínio do inacessível em que se dissimulariam penosas verdades, esse projeto revelaria ao homem que, a partir da leitura, ele deverá se abrir a tudo o que mais violentamente o revolta. Mais ainda, enquanto perverso experimento, La marchande d'enfants mostraria que aquilo que nos revolta estaria incutido em nós mesmos. $\mathrm{O}$ romance epistolar de Wittkop, que reitera mais uma vez a presença essencial da violência, da morte em sua literatura, seria por fim uma abordagem emocional para com o mundo, com as ruelas sombrias da história humana e, por que não, para com seu leitor.

38 Tradução nossa. No original: Si les gens sont choqués, ça prouve qu'ils sont simplement 'choquables', c'est tout ! 


\section{Referências}

BATAILLE, Georges. L'érotisme. Paris: Les éditions de minuit, 1957. O erotismo. Tradução de Antonio Carlos Viana. São Paulo: L\&PM, 1987.

BATAILLE, Georges. La littérature et le mal. Paris: Gallimard, 1957.

BATAILLE, Georges. Les larmes d'Éros. Paris: Pauvert, 1961.

COSTA LIMA, Luiz. Mímeses: desafio ao pensamento. Rio de Janeiro: Civilização brasileira, 2000.

DELEUZE, Gilles. Sacher-Masoch: o frio e o cruel. Tradução de Jorge Bastos. Rio de Janeiro: Jorge Zahar, 2009.

FARRAR, Roxanne Claire. Violence and différance in the literature of the marquis of Sade. Sartrean dialectics: a Method for Critical Discourse on Aesthetic Experience. Amsterdam-Atlanta: Rodopi, 2000

FLEURY, Cynthia (Org.). Imagination, imaginaire, imaginal. Paris: Presses Universitaires de France, 2006.

FOUCAULT, Michel. Language, madness and desire: on literature. Minnesota: University of Minnesota Press, 2015.

FOUCAULT, Michel. La grande étrangère. Paris: EHESS, 2013.

LE BRUN, Annie. Sade soudain un bloc d'abîme. Paris: Gallimard, 1986.

MACMORRAN, Will. The sound of violence: listening to rape in Sade. Disponível em: https:// www.academia.edu/4891573/The_Sound_of_Violence_Listening_to_Rape_in_Sade, Acesso em: 24 de fev. de 2016.

VÁRIOS. La douleur: beauté ou laideur. Lleida: Universidad de Lleida, 2005.

YOUNG, Paul J. Seducing the Eighteenth-century French Reader: Reading, Writing, and the Question of Pleasure. Farnham: Ashgate Publishing, Ltd., 2008.

WITTKOP, Gabrielle. La Marchande d'enfants. Paris: Éditions Verticales, 2003. 